\title{
A REVIEW OF THE SYNENTOGNATHOUS FISHES OF JAPAN.
}

\author{
By David Starr Jordan and Edwin Chapin Starks, \\ Of the Leland Stanford Junior University.
}

In this paper is given an account of those fishes of Japan belonging o the suborder of Synentognathi. The material examined belongs to he United States National Museum and to the Leland Stanford Junior Iniversity, most of it having been collected by Messrs. Jordan and inyder during the summer of 1900.

\section{Suborder SYNENTOGNATHI.}

Lower pharyngeal bones fully united; second and third superior haryngeals variously enlarged, not articulated to the cranium, sendng processes forward; the fourth small or fused with the third. Tertebræ numerous ( 45 to 70 ), the abdominal ones much more tumerous than the caudal. Ventral fins abdominal, without spine, be rays more than five. Scapula suspended to the cranium by a ost-temporal bone, which is usually simple, furcate in Belonidæ. Articular bone of lower jaw with a small supplemental bone perhaps orresponding to the coronoid bone. Parietal bones usually absent, vhen present much reduced, well separated by the supraoccipital. fupraclavicle small when present; no interclavicles. No mesocoraoid. Maxillary very close to premaxillary and sometimes firmly oined to it, the suture always distinct. Basis of cranium double in ront, but without muscular tube. No adipose fin. Fins without pines. Lateral line concurrent with the belly, peculiar in structure. tir bladder usually large, without pneumatic duct. Intestinal tract imple, without pyloric cæca. This order is allied to the Haplomi on he one hand and to the Percesoces on the other, and, like these roups, it marks the transition from the soft-rayed to the spiny-rayed ishes. In their anatomical characters the Synentognathi most resemle the latter, but there are never spines in the fins, and the lower sharyngeals are united. The group is divisible into four closely :elated families, which have usually been regarded as divisions of one

Próoceedings U. S. National Museum, Vol. XXVI-No. 1319 ,

Proc. N. M. vol. xxvi-02--36 
family, Exocotidx or Scombresocidx. The remarkable differences in the pharyngeals seem to us to permit the division of the group into. four families.

( $\sigma \dot{v} v$, together; हैv, within; $\gamma v \alpha \dot{\alpha} \theta o s$, jaw.)

a. Third superior pharyngeal on each side scarcely enlarged, not longer than its anterior process, and armed with comparatively few (about 15) pointed teeth; fourth superior pharyngeal distinct on each side; lower pharyngeals united into a small linear plate, armed with small teeth; vertebræ with zygapophyses; both jaws produced in a long beak in the adult (the upper short in the young); teeth in jaws strong, unequal; maxillaries firmly appressed to the premaxillaries; a distinct suture along the boundary; "coronoid" bone (attached to the articular) evident. Species carnivorous .............................. aa. Third superior pharyngeal greatly enlarged, covered with bluntish, tricuspid teeth; fourth superior pharyngeal wanting or fused with the third; lower pharyngeals large, fused into a thick triangular bone with transversely concave surface, covered with blunt, tricuspid teeth; teeth in jaws always small, conic, or tricuspid; maxillary close to premaxillary, but not suturally joined to it, there being some open space between; coronoid bone small, but present; no canine teeth; no zygapophyses to the vertebræ.

b. Third superior pharyngeal solidly joined with its fellow to form an ovoid plate, which sends two processes forward; cleft of mouth narrow; the lower jaw usually produced; teeth of jaws tricuspid; herbivorous species.

Hemiramphide, 2.

$b b$. Third superior pharyngeals more or less closely appressed, but not united; species at least partly carnivorous.

c. Dorsal and anal fins each with several detached finlets; cleft of mouth long, both jaws being more or less produced in a pointed beak; paired fins small. Scombresocide, 3.

$c c$. Dorsal and anal without finlets; cleft of mouth short, the jaws not produced in a beak; pectoral fins more or less produced, forming an organ of flight. ExOCETIDE, 4.

\section{Family I. BELONIDA.}

\section{NEEDLE-FISHES.}

Body elongate, very slender, compressed or not, covered with small, thin scales. Lateral line very low, running as a fold along side of belly. Both jaws produced in a beak, the lower jaw the longer, very much the longer in the young, which resemble Hemiramphus; maxillaries grown fast to premaxillaries; each jaw with a band of small, sharp teeth, besides a series of longer, wide-set, sharp, conical teeth. No finlets. Dorsal fin opposite anal, both fins rather long. Air bladder present. Lower pharyngeals united to form a long, slender, narrow plate, with flat surface, covered with small, pointed teeth; upper pharyngeals distinct, the third pair little enlarged, each with some 15 moderate, unequal, pointed teeth (Tylosums marinus); fourth pair well developed, with similar teeth, but without anterır processes. Vertebræ numerous, with zygopophyses. Ovary single. Voracious, carnivorous fishes, bearing a superficial resemblance to the gar pikes; 
found in all warm seas, sometimes entering rivers. Their habits are ordinarily much like those of the pike, but when startled they swim along the surface with extraordinary rapidity, often leaping above the water for short distances. When thus leaping the large species of the tropics are sources of danger to incautious fishermen, sometimes piercing the naked abdomen of the natives. Most of them are good food-fishes, but the green color of the bones of the larger species often causes them to be avoided, for no good reason.

a. Gill rakers wanting; no teeth on vomer; anterior rays of dorsal and anal elevated.

Tylosurus, 1 .

\section{TYLOSURUS Coceo.}

Tylosurus Cocco, "Lettere in Giornale Sci. Sicilia, XVII," 1829, p. 18 (cantraini=imperialis).

Body elongate, very slender, not much compressed. Both jaws prolonged into a beak the lower jaw somewhat the longer, much the longer in young fishes, the very young resembling Hemiramphus. Each jaw armed with a band of small, sharp teeth, beside which is a series of longer, wide-set, sharp, conical, unequal teeth; no teeth on vomer or palatines. Scales small, thin; lateral line running along the side of the belly, becoming median on the tail. No finlets. Dorsal fin more or less elevated anteriorly; caudal fin short, unequally lunated or forked; pectorals moderate; ventrals small, the latter inserted behind the middle of the body. Gill rakers obsolete. Bones usually more or less green. Size comparatively large. Species numerous. Voracious fishes, chiefly American; one species crossing to Europe; some of them entering rivers. This genus differs from the Old World genus, Belone Cuvier, in the absence of gill rakers and of vomerine teeth. ( $\tau$ v́dos, callus; ov́pá, tail; in allusion to the caudal keel, on which the genus was originally based, a character of little importance.)

a. Dorsal rays about 25 .

b. Lateral line not forming a black keel on caudal peduncle. Posterior dorsal rays produced to form a rounded lobe as high or nearly as high as produced anterior lobe, these rays longest in the young. Jaws slender and long; upper jaw from anterior orbital rim $2 \frac{1}{2}$ times longer than length of rest of head.

schismatorhynchus, 1.

$b b$. Lateral line extending on caudal peduncle, forming a low black keel.

c. Jaws short and stout; upper jaw from anterior orbital rim $1 \frac{2}{3}$ longer than rest of head; posterior rays of dorsal elevated; size very large...... giganteus, 2. cc. Jaws slender and long; posterior rays of dorsal short; body scarcely com-

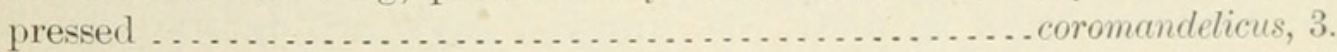

aa. Dorsal rays about 18; posterior rays of dorsal short. Body much compressed, the width one-half the depth; caudal peduncle much compressed, without

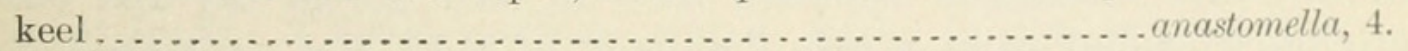




\section{TYLOSURUS SCHISMATORHYNCHUS (Bleeker).}

DATSU,

Belone gracilis Schlegel, Fauna Japonica, Poiss., 1846, p. 246, pl. cx, fig. 1; Nagasaki; not of Lowe, 1839, a species from Madeira.-BLeek er, Nieuwe Nalez., Japan, 1857, p. 116.-Nystrom, Svensk. Vet. Akad. Handl., 1887, p. 44; Nagasaki.

Mastacembelus gracilis Bleek ER, Ned. Tyds. Dierk., 1866, p. 111.

Belone schismatorhynchus Bleeker, Nat. Tydschr. Ned. Ind., I, 1850, p. 95.Bleeker, Verh. Gen., XXIV, 1866, p. 15.-Günther, Cat. Fish, VI, 1866, p. 239; Mozambique, Zanzibar.-Ishrkawa, Prel. Cat., 1897, p. 18; Boshu.

Mastacembelus schismatorhynchus BLEEKER, Atlas Ichth. Ind. Belon., about 1870, p. 49; Java, Ternate, Nagasaki.

Head from tip of upper jaw $4 \frac{1}{4}$ to $4 \frac{1}{2}$ in length; depth equals postorbital part of head; dorsal 24 to 27 ; anal 25 to 27 .

Body very elongate and rather strongly compressed, the sides vertical and parallel. Dorsal and anal outlines parallel from head to dorsal. Jaws very slender and long; upper jaw from anterior orbital rim $2 \frac{1}{2}$ times longer than rest of head. Premaxillary toward base constricted slightly and strengthened above by a mass of bone along the posterior fourth of the length, which ends in a point as viewed from above. Diameter of eye equals interorbital width and is contained 2 to $2 \frac{1}{8}$ in postorbital part of head. Top of head from above eyes to occiput smooth with a translucent cartilage-like tissue. Nostril an elongate, somewhat triangular pit containing a simple undivided papilla. Head apparently naked except a patch of scales above cheeks and another on top of head from eyes to base of mixillary.

Pectoral equal to postorbital part of head or sometimes slightly longer. Ventrals inserted nearer the anterior margin of the eye than the base of the caudal by a distance equal to a diameter of the eye, their length twice the diameter of the eye. Anal placed well in advance of dorsal; the base of the sixth ray under the base of the first dorsal ray, the anterior part of anal strongly concave on its posterior margin. Distance of base of last anal ray from base of auxiliary caudal rays $1 \frac{1}{4}$ to $1 \frac{1}{6}$ times the diameter of the eye; the last ray reaches a little over half this distance. Distance from front of anal to base of ventrals is contained 5 times in length from middle of eye to caudal base; the anal base exceeds this length by $1 \frac{1}{2}$ times the diameter of the eye. Dorsal scarcely so strongly concave behind the anterior rays as anal; its longest rays are behind the middle. When fin is depressed the tip of eighth ray from the last reaches base of last ray. Distance between base of last dorsal ray and base of auxillary caudal rays equals diameter of eye; the depressed dorsa reaches five-sixths of this distance. Median caudal rays about half the length of longest rays of lower caudal lobe, which is a little longe: than the upper. The lateral line is not at all produced as a keel or caudal peduncle. 
Color in spirits: A bluish diffused lateral band follows the contour of back, running from the pectoral base to just above the middle of the caudal base, growing narrower posteriorly. Above lateral band the body is greenish or brownish; below uniformly bright silvery. Upper part of head dark, except translucent cartilaginous area; base of upper jaw black; head otherwise silvery. Distal half of pectoral black; outer rays and tips of ventrals dusky; anterior rays of anal dusky toward tips; dorsal blackish, except bases of anterior rays, the rays usually green; caudal dusky.

Here described from specimens from Nagasaki $45 \mathrm{~cm}$. in length. Other specimens are from Wakanoura.

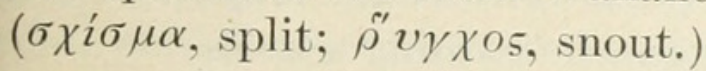

\section{TYLOSURUS GIGANTEUS (Schlegel).}

OKIZAYORI (OFFSHORE NEEDLEFISH).

? Belone indica Le Sueur, Journ. Ac. Nat. Sci. Phila., II, 1821, p. 131; India.

Belone gigantea Schlegel, Fauna Japonica, Poiss., 1846, p. 245; Nagasaki.Bleek er, Ac. Soc. Indo-Nederl., III, Japan, p. 21.

Belone annulata Cuvier and Valenciennes, Hist. Nat. Poiss., XVIII, 1846, p. 447; Celebes, Friendly Islands, Seychelles, Pondicherry.

Belone annulata Günther, Cat. Fish., VI, 1866, p. 240; Pinang, China.-IshIKAWA, Prel. Cat., 1897, p. 18; Tokyo, Formosa.

Mastacembelus annulatus Bleek er, Atlas Ichth. Belon., 1870, p. 48; Java, Madura, Bawean, Cocos, Sumatra, Singapore, Celebes, Pinang, Batjan, Ternate, Amboina, Gilolo.

? Belone melanurus Bleek ER, Verh. Bat. Gen., XXII, 1849, p. 11.

Belone cylindrica Bleeker, Verh. Bat. Gen., XXIV, 1851, p. 13.

?Belone brachyrhynchus Bleeker, Nat. Tyds. Ned. Ind., VI, 1854, p. 61; Gilolo, young.

Head from tip of lower jaw $3 \frac{3}{5}$ in length; depth at ventrals $1 \frac{1}{5}$ in oostorbital part of head. Dorsal 23; anal 21.

Body as wide as deep to within a short distance of dorsal, the nterorbital space and head above gently convex. Jaws rather short nd stout, the lower slightly the longer; their sides nowhere parallel ut approaching rather rapidly to a point. Length of snout from nterior margin of eye equal to the distance from same point to middle f longest pectoral rays. Eye one-third of postorbital part of head, ne-half of interorbital. Interorbital space with two low ridges, sepaated from each other by a space equal to two-thirds diameter of eye, npreceptibly diverging anteriorly. Between them are two narrower, horter, parallel ridges separated by a space one-third of diameter of ye. Nostrils broad, triangular, containing a fleshy process divided ito many folds. Cheeks entirely scaled; scales on top of head before yes to base of premaxillary.

Length of pectoral equals postorbital part of head and one-third re. Length of ventrals contained $2 \frac{1}{4}$ times in space between their ise and front of anal. Insertion of ventrals midway between middle 
of eye and base of caudal. Front of anal directly under front of dorsal, its base shorter than that of dorsal by three-fourths diameter of eye, and equal to the distance between ventrals and anal. Outline of dorsal and anal deeply concave behind anterior rays. Anterior rays of the latter longer than those of dorsal. Base of the last anal ray distant from base of auxilliary caudal rays twice the distance from last dorsal ray to the corresponding caudal ray. Anterior dorsal rays longer than the long posterior dorsal rays. When dorsal is depressed the seventh from the last ray reaches to the base of the last ray and the tips of the last few rays barely reach the base of the auxiliary caudal rays. Caudal evidently forked, the lower lobe the longer. Lateral line strongly produced on caudal peduncle forming a keel.

Silvery on sides and lower parts growing rather gradually greenish on back. Top of head and upper jaw black. A long black blotch at edge of preopercle. Dentate margin of lower jaw black; head otherwise silvery. Inner face and posterior part of outer face dusky. Ventrals dark except inner rays. Anterior ray of anal dusky. Dorsal and caudal blackish. Lateral line on caudal peduncle black.

Here described from a single specimen from Nagasaki, 33 inches in length.

A young specimen of this or some closely related species from Wakanoura differs in having the posterior rays of the dorsal lengthened to well beyond the base of caudal (when the dorsal is depressed), the caudal scarcely forked and with a black blotch at its base, the eye. of course, much larger and the general color much darker and without silvery pigment. It is but $12 \mathrm{~cm}$. in length.

According to Bleeker the type of giganteus examined by him in the Leyden Museum is identical with annulatus. The name giganteus i apparently the earlier of the two, but indicus, about the pertinence 0 which there is some doubt, is earlier than either. A species appar ently identical with these occurs in Hawaii and in Samoa.

\section{TYLOSURUS COROMANDELICUS (Van Hasselt).}

Belone coromandelicus Van Hasselt, Alg. Konst., 1823, p. 130; Coromande according to Bleeker.

Belone timucoides de Ferussac, Zool., 1823, p. 372, after Van Hasselt.

Belone melanotus Bleeker, Nat. Tyds. Ned. Ind., I, 1850, p. 94.-Bleeker, Ver Genootsch., XXIV, 1851, p. 14.-Günther, Cat. Fish., VI, 1866, p. 239; Ea Indies.

Mastacembelus melanotus Bleeker, Atlas Ichth. Ind. Belon., 1870, p. 47; JaI Singapore, Molucca, Celebes.

Head $3 \frac{1}{2}$ in length; depth exceeds postorbital part of head by on fourth eye. Dorsal 25 or 26 ; anal 23 or 24 .

Body scarcely compressed. Head nearly flat between eyes. Ja rather slender and long. Snout from anterior margin of eye equal twice the distance from same point to edge of opercle. Eye one-h: 
postorbital part of head, five-sixths of interorbital width. Interorbital rough, with longitudinal striations; a shallow groove along its middle.

Length of pectoral equals depth at ventrals, or $2 \frac{2}{3}$ in dorsal base. Length of ventrals contained $2 \frac{3}{4}$ times in space between their base and front of anal. Ventrals inserted midway between caudal base and posterior third of eye. Anal a little in advance of front of dorsal, its base shorter than that of dorsal by the diameter of eye. Outline of dorsal and anal deeply concave behind anterior rays. Anterior rays of dorsal equal in length to those of anal. Base of last anal ray twice the diameter of eye distant from base of auxiliary caudal rays. Last dorsal ray three-fourths eye from auxiliary caudal rays. Posterior dorsal rays not much elongated; the longest scarcely as long as eye; the third ray from the last reaches base of last ray in reclined fin; the last ray reaches three-fifths the distance between its base and base of auxiliary caudal rays. Caudal not deeply forked, the lower lobe much the longer. Lateral line on caudal peduncle slightly raised to a keel which is black.

Color in spirits: Greenish on back, silvery below; jaws and teeth green; pectoral dusky toward tips of rays; axil black; tips of front dorsal rays dusky, and dorsal black behind; tip of middle anal rays black; dorsal dusky.

Here described from a specimen $78 \mathrm{~cm}$. in length from Tsuruga. Another specimen is in the collection from Yokohama.

There is no other record of the species from Japan. It is apparently frequently taken in the East Indies.

(Coromandelicus, from Coromandel.)

\section{TYLOSURUS ANASTOMELLA (Cuvier and Valenciennes).}

\section{DATSU.}

Belone anastomella Cuvier and Valenciennes, Hist. Poiss., XVIII, 1846, p. 446; China.-Günther, Cat. Fish., VI, 1866, p. 249; Shanghai, Japan, India.Ishikawa, Prel. Cat., 1897, p. 18; Tokyo.-Steindachner and Döderlein, Fische Japans, IV, 1887, p. 37; Tokyo.

Tylosurus anastomella JoRdAN and SNYDER, Check List Fishes, Japan, 1901, p. 61;
Yokohama.

Belonia ciconia

by Reeves.

Depth at ventral fins $1 \frac{1}{5}$ in postorbital part of head, which is $9 \frac{1}{3}$ in ength from opercle to base of caudal. Dorsal, 18; anal, 23.

Body compressed, the width a little less than half depth. Tips of aws broken in all our specimens; upper jaw to eye at least $3 \frac{4}{5}$ from ame point to base of caudal. Eye $3 \frac{4}{5}$ in postorbital part of head, even-eighths of interorbital width. Interorbital with a wide, shallow hannel along its middle. Base of upper jaw not strengthened by a ony ridge, but outline of head evenly and slightiy concave from 
occiput to tip of jaw. Nostril as broad as deep, triangular. Suborbital space equal to depth of eye. Teeth rather slender; no teeth on palate.

Length of pectoral $1 \frac{1}{4}$ in postorbital part of head. Ventrals inserted midway between base of pectoral and base of caudal, their length twothirds that of pectoral. Base of eighth anal ray under first dorsal ray. Base of anal slightly less than space between its first ray and ventrals. Anterior anal rays longer than those of dorsal, or $1 \frac{3}{5}$ in postorbital part of head. Base of last anal ray one-half diameter of eye anterior to base of last dorsal ray. Space between last anal ray and auxiliary caudal rays equal to length of anterior anal rays. Base of dorsal $1 \frac{1}{4}$ in that of anal. Lower rays of caudal scarcely longer than upper rays; the caudal scarcely forked, lunate when fin is extended. Caudal peduncle compressed, without keel.

Color in spirits: A narrow bluish silvery lateral band, following outline of back, runs from above pectoral to caudal base; above the back is abruptly brownish; below the sides and belly are uniformly bright silvery; top of head dark; a dark band along posterior upper part of preopercle; tip of pectoral dusky; axil colorless; dorsal and caudal dark.

Here described from a specimen $70^{\circ} \mathrm{cm}$. in length from Yokohama. Other specimens are from Tokyo, Matsushima, and Hakodate. It is not certain that the name anastomella is prior to ciconia, but the description is better.

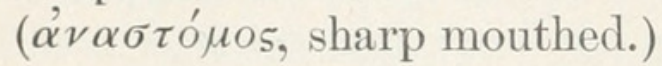

\section{Family II. HEMIRAMPHID A.}

\section{HALF-BEAKS.}

Body elongate, more or less compressed, covered with large cycloid scales; upper jaw short, lower jaw various, sometimes much produced, the toothed portion at base fitting against the toothed premaxillaries; teeth equal, mostly small and tricuspid; maxillaries anchylosed to premaxillaries. Gill rakers long. Caudal fin rounded, or forked; if forked, the lower lobe the longer. Anal fin modified in the viviparous species (Zenarchopterus), unmodified in the others and usually similar to the dorsal; no finlets; air bladder large, sometimes cellular. Third upper pharyngeal on each side much enlarged, solidly united with its fellow to form an oval plate, with slightly convex surface and covered with blunt tricuspid teeth; this is about as large as the united lower pharyngeals, and fits into the concavity of the latter; fourth upper pharyngeal wanting or grown fast to the third; lower pharyngeal large, thick, triangular, with concave surface. Vertebræ about 50.

Herbivorous tishes of the warm seas; mostly shore species; a few pelagic, a few confined to fresh water. They feed chiefly on green algæ, and, like the related forms, swim at the surface, occasionally 
Body not much compressed. Mandible not extremely elongate, its length from posterior angle of mouth equal to distance from same point to base of pectoral. Upper jaw a little longer than wide. Gill rakers slender, the longest half the diameter of eye, $8+21$ in number.

Top of head and tip of upper jaw scaled to tip, the scales more imbricated than in $H$. Kurumeus. Sides of mandible with scales; 74 scales in a median row on back between dorsal fin and occiput.

Dorsal and anal opposite to each other and of about the same length; base of dorsal equal to distance from tip of upper jaw to posterior of eye. Ventrals inserted midway between anterior margin of eye and tips of median caudal rays. Length of pectoral equals postorbital part of head and half eye. Lower caudal lobe the longer, as long as base of dorsal. The middle rays not quite twice the diameter of eye.

Color in spirits: Brownish above, silvery below lateral stripe; scale pouches outlined with dark-brown dots on back. Sides of head silvery; mandible black; top of head and upper jaw dusky or black; lateral stripe distinct, widest under front of dorsal, outlined above by a dusky stripe. Dorsal and caudal dusky, other fins colorless.

Here described from a specimen $25 \mathrm{~cm}$. in entire length from Aomori.

The young of this species agree very well with Dr. Gill's description of $I$. occipitalis (which was taken from a specimen 4 inches in length) except that his specimen is alleged to have fewer anal rays and 2 or 3 fewer dorsal rays. Owing to the small size of his type, a mistake of this sort might easily be made. No species other than $H$. sajori has been recognized along the coast of Hondo. Specimens were collected in salt water at Nagasaki, Matsushima, Aomori, Same, Tokyo, Misaki, Wakanoura, Kobe, and Hakata. It is one of the commonest fishes of Japan, much used for food.

(sayori, the vernacular name.)

6. HYPORHAMPHUS KURUMEUS Jordan and Starks, new species.

Head from tip of upper jaw 5 in length; depth 10 to 11 . Dorsal 15 or 16 ; anal 17 or 18 ; scales 70 .

Body not much compressed, the depth appearing greatest just behind opercles. Lower jaw from tip of upper half length of head; upper jaw slightly longer than wide. Teeth in upper jaw in a straight band at extreme sides, becoming broader anteriorly; those in lower jaw in a band narrower than the band at front of upper jaw and becoming narrower anteriorly. Eye equal to interorbital space, and contained twice in postorbital part of head. Gill rakers slender, scarcely as long as pupil, $7+19$ in number.

Scales on top of head extending to snout. They are scarcely imbricated, circular, and with concentric striations, which form complete circles; similar scales on sides of mandible; from 47 to 50 scales in a median series on back between occiput and front of dorsal. 
body 9 times, and origin of dorsal to center of caudal a little less than one-fifth of length. Origin of anal to center of caudal 7 times and to origin of ventrals $3 \frac{3}{4}$ in total length. Lower lobe of caudal $6 \frac{1}{4}$ times in same distance; upper lobe one-third shorter and much narrower. Eye $2 \frac{1}{2}$ in depth. Head and beak strong and stout. Body of equal height as far as ventrals. Pectorals pointed and equal to height of body in length. Ventrals with emarginate border, first and last ray of equal length. Dorsal with first ray nearly as long as height of body, with emarginate border, and last rays quite short. Anal beginning under middle of dorsal, and resembling it in form, but smaller. Caudal so deeply forked that it appears separated into two distinct lobes. Lower lobe longest and broadest, both pointed. Scales large, appearing to resemble those of Hyporhamphus commersonii.

Color bluish, darkest on back, lighter below. A tinge of green on sides and upper lobe of caudal. A narrow strip of green on middle of sides reaching from pectoral to caudal, with a broader stripe of pale silvery blue, tinged with greenish, bordering it on each side. Lower jaw dark indigo blue toward the tips, lighter toward the head. Fins all pale bluish, caudal dark dusky blue. Scales on back appear to have darker on their margins. (Brevoort.)

This species has not been seen since the drawing was made from which Brevoort compiled his description. His type was from Nafa, in the Riukiu Islands (Okinawa). The species is very doubtful and may not differ from $H$. sajori.

\section{Family III. SCOMBRESOCIDA.}

Body elongate, compressed, covered with small, thin, deciduous scales, the general aspect being that of a mackerel. Both jaws in the adult more or less prolonged, forming a slender beak, the upper jaw always the longer; teeth very feeble, pointed; maxillaries joined fast to premaxillaries, pectoral and ventrals small; dorsal and anal low, similar to each other, each with 4 to 6 detached finlets, as in the Scombridx; gill rakers numerous, long and slender. Pharyngeal bones essentially as in Exocotus; fourth upper pharyngeal on each side wanting or fused with the third; third pharyngeal greatly enlarged, separate from its fellow, covered with tricuspid teeth; second with simple teeth; first toothless; lower pharyngeals united, forming a triangular bone with concave surface, covered with tricuspid teeth; into the hollow of this bone the upper pharyngeals fit. Species few; pelagic fishes, swimming close to the surface in large schools in temperate regions. They bear strong analogical resemblances to the mackerels in form, color, and habits, as well as in the dorsal and anal finlets. The significance of this resemblance is unknown.

a. Jaws produced in a short beak, about half-length of rest of head.... Cololabis, 3. 


\section{COLOLABIS Gill.}

Cololabis Gill, Proc. U. S. Nat. Mus., XVIII, 1895, p. 176.-Jordan and Everman, Fishes North and Middle Amer., I, 1896, p. 726 (brevirostris.)

This genus is close to Scombresox, differing chiefly in the very short beak, the upper jaw, even in the adult, not being at all produced, and the lower jaw having only a short flexible tip. This genus represents the immature state of Scombresox.

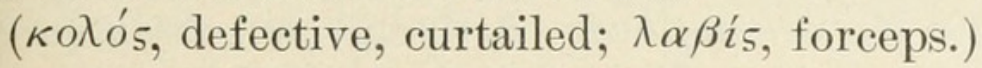

\section{COLOLABIS SAIRA (Brevoort).}

\section{SAMMA.}

Scombresox saira Brevoont, Perry's Exp. to Japan, 1856, p. 281, pl. vir, fig. 4 (on a drawing).--Ishikawa, Prel. Cat., 1897, p. 18; Tokyo.

Scombresox saurus Nystrom, Svensk. Vet. Akad. Handl., 1887, p. 46; Nagasaki, not of Walbaum.

Head, including tip of lower jaw, $4 \frac{1}{2}$ in length; depth $7 \frac{3}{4}$. Dorsal 10 to $12-\mathrm{V}$ or VI (rarely VI); anal 12 to 14 - VI or VII; scales 120.

Body elongate and much compressed, the width of head $1 \frac{1}{2}$ the diameter of eye. Eye placed exactly between tip of mandible and edge of opercle, its diameter contained $2 \frac{1}{4}$ in snout. Teeth extremely small, in a single scattered row on edge of jaws, sometimes not evident. Maxillary produced to a sharp point; as viewed from above it is as long as broad. Mandible projecting to a short point, which enters upper profile when mouth is closed. Interorbital width equals diameter of eye, opercle and subopercle together forming a broad plate continuous on lower outline with that of the rest of head and ending behind in a blunt right angle. Gill rakers slender and numerous, as long as three-fifths the diameter of eye, 27 on lower part of arch. Gill slit not open above upper ray of pectoral. Top of head to tip of upper jaw with scales. One or two specimens show slight traces of large scales on opercles, cheeks, mandible, and preorbital. Usually, however, no trace remains, and in none of our numerous specimens are there any scales remaining in this region. Scales on body caducous, about 90 in a median row between occiput and dorsal. Pectoral short and broad, the lower rays growing rapidly shorter, its length twice diameter of eye. Ventrals inserted midway between base of caudal and middle of eye. Front of anal half the diameter of eye in advance of dorsal. Dorsal and anal finlets connected to body by an extremely thin delicate membrane which is usually broken and not evident, but through our large series it has been found with each finlet but the last.

Color in spirits abruptly silvery on lower half of body, above which is usually a bluish silvery lateral band nearly as wide as eye. Back 
above lateral band abruptly slaty blue. Top of head to tip of upper jaw dark. Dorsal, caudal, and inner surface of pectoral dusky. Base of pectoral dusky. Other fins colorless.

Here described from numerous specimens 15 to $18 \mathrm{~cm}$. in entire length, from Awa, obtained from Yonekichi Koneyama, a local naturalist.

Other specimens are from Otaru, Aomori, and Hakodate, the longest $29 \mathrm{~cm}$. in length. It is locally known as Samma. The name Saira (Sayori) is used only for Hyporhamphus. Although not recognized by any author except Ishikawa since Brevoort, the species is common, running in large schools in sheltered bays from Tokyo northward. Nystrom's Scombresox saurus with shorter snout ("mendre ut dragen nos") is evidently Cololabis saira. The figure of Brevoort does not show correctly the number of finlets, which are 6 or 7 , as in 5 combresox saurus. The rare Californian species, Cololabis brevirostris, is close to Cololabis saira.

(Saira [Sayori], Japanese name of Hyporhamphus.)

\section{Family IV. EXOCCETIDA.}

\section{FLYING-FISHES.}

Body oblong or elongate, covered with cycloid scales, which are rather deciduous. Lateral line running very low, along the sides of the belly. Head more or less scaly, with vertical sides. Mouth moderate, terminal, the jaws not prolonged into a long beak. Premaxillaries not protractile, hinged at base mesially; margin of the upper jaw chiefly formed by the premaxillaries; the short maxillaries entering the lateral margin; maxillary free from the premaxillary, its edge slipping under the front of the preorbital. Dentition various, the teeth small and weak. Dorsal fin without spines, inserted on the posterior part of the body, opposite the anal and more or less similar to it; ventrals abdominal, of several soft rays, inserted posteriorly; pectoral fin inserted high, used as an organ of flight; shoulder girdle and pectoral muscles very strong; caudal fin forked, the lower lobe the longer. No finlets. Vent close in front of anal. Nostrils large, double, near the eye. Lower pharyngeals enlarged and fully united, forming a large, transversely concave plate, covered with large, closeset, blunt, tricuspid teeth; third upper pharyngeal greatly enlarged, not united with its fellow, both covered with large, blunt, tricuspid teeth; fourth superior pharyngeal wanting in the adult (probably coossified with the third; vertebræ without zygapophyses. Gill membranes not united, free from the isthmus. Pseudobranchiæ hidden, glandular. Gill rakers various. Gills 4, a slit behind the fourth. Air bladder very large, not cellular, so far as known, and extending far backward among the hæmapophyses of the caudal vertebræ. Vertebræ 
midway between the base of the caudal and the posterior margin of the eye; they reach slightly past the tips of the pectorals. The inner part of the second ray and the outer part of the third protrude beyond the tips of the other rays and form a sharp angle. The outer rays of the ventrals are not graduated. The first or outer ray is scarcely over a third as long as the longest part of the second.

Color in spirits a clear light brown above, silvery below. The membrane of the pectoral is dark brownish, without spots or markings. The rays on the outer side are silvery, making the fin appear silvery when closed. Ventrals brown like pectorals, with the inner and outer ray very light. Anal colorless and dorsal colorless, except for a small dark brown spot at tips of fifth and sixth rays. Caudal dusky.

Here described from a small specimen from Misaki, presented by the Imperial University of Tokyo. It is $13 \mathrm{~cm}$. in length. It is probably rare in Japan, drifting northward in the warm current, or Kuro Shiwo. It was originally described from China. It has been identified, probably incorrectly, with the European species, Exonautes rondeleti.

( $\beta \rho \alpha \chi v^{\prime}$, short; $\kappa \varepsilon \phi \alpha \lambda \dot{\eta}$, head.)

\section{CYPSILURUS Swainson.}

Cypsilums Swainson, Classification Fishes, etc., II, 1839, p. 296 (nuttalli, based on young with barbels).

Body elongate, broad above, somewhat compressed. Head short, blunt, narrowed below. Mouth small. Jaws very short, about equal. Chin without barbel in the adult, often with one or two long fragile barbels in the young. Maxillaries not joined to the premaxillaries. Teeth very feeble or wanting. Eyes large. Gill-rakers moderate. Scales large, deciduous. No finlets. Dorsal fin short, opposite anal, which is shorter than dorsal, of nine or ten rays. Caudal widely forked, the lower lobe the longer. Pectoral fins very long, reaching past the beginning of the anal, and serving as organs of flight, their great size enabling the fish to sustain themselves in the air for some time. Ventral fins large, posteriorly inserted, also used as organs of flight. Air bladder very large. No pyloric cæca. Species numerous in all warm seas, living mostly in the open water and swimming in great schools. The species are largely cosmopolitan and are the largest of the flying fishes.

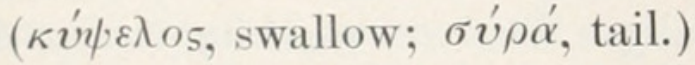

a. Second pectoral ray divided.

$b$. Ventrals pale or slightly dusky.

c. Pectoral fins unspotted, reaching nearly to end of dorsal: D. 13 . A. 9;

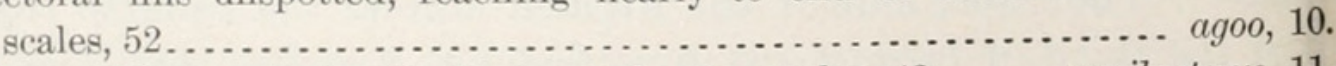

cc. Pectoral fins spotted with black; anal pale; scales, 42 . ..... precilopterus, 11.

bb. Ventrals mostly jet black; anal black posteriorly; fins all dark: D. 12. A. 9. 
The above description is taken from specimens 10 to 12 inches long from Nagasaki.

Numerous specimens were collected at Tsuruga, Nagasaki, Tokyo, Myiako (north of Sendai), Hiroshima, Hakata, Onomichi, and Aomori.

It is the common flying-fish or Tobis-Uwo of Japan, abundant all along the coast in the summer. It is subject to a number of variations, but all specimens examined by us seem to belong to one species. Exocotus döderleini is evidently identical with Cypsiturus agoo.

(agu, a vernacular name, now rarely used.)

\section{CYPSILURUS PECILOPTERUS (Cuvier and Valenciennes).}

Exoccetus pecilopterus Cuvier and Valenciennes, Hist. Poiss., XIX, p. 112, pl. DCXI; New Britain.-Günther, Cat. Fish., VI, 1866, p. 291; Formosa.

Exocoetus, sp. No. 309, Ishikawa, Prel. Cat., 1897, p. 18; Hakodate.

A specimen in the Imperial Museum at Tokyo is probably referable to the above species. The following notes were taken on this specimen:

Scales 42, 24 before dorsal; anal short; head flattish above; body rather plump; pectoral reaching to middle of dorsal, its second ray divided; dorsal low; ventrals reaching past front of anal.

Color: Ventrals dusky behind, perhaps faded; dorsal unspotted; pectorals profusely and coarsely spotted with black, the spots unequal. According to Günther the dorsal has 12 or 13 rays, the anal 9, the distance from first dorsal ray to first of caudal being much greater than length of head.

Described from a stuffed specimen, 10 inches in length, taken at Hakodate. It is questionable whether this species is really identical with $C$. pacilopterus, but no other described species agrees as well.

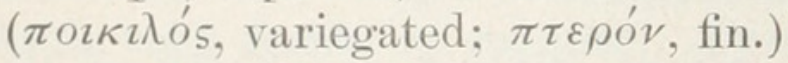

\section{CYPSILURUS HIRUNDO (Steindachner.)}

Exocotus hirundo Steindachner, Ichthyol. Mittheil., VIII, 1866, p. 482, pl. Iv, fig. 2; Hongkong.

Head $4 \frac{1}{2}$ in length; depth $6 \frac{3}{4}$. Dorsal 12; anal 9 ; scales about 53 . Body not compressed, about as wide as deep, the head short, widest at a level with upper edge of pupil; its width equal to distance from edge of opercle to middle of eye. Eye two-fifths longer than snout, contained $1 \frac{1}{6}$ times in postorbital part of head. Lower jaw projecting, the tip injured in our specimen and the barbels missing. The interorbital space is wide and shallowly concave, its width a little greater than the diameter of the eye. Snout short and broad at the anterior margin of the eyes; its width is three-fifths of its length.

The pectoral reaches to under the seventh or eighth dorsal ray. Its upper ray is undivided and is contained $2 \frac{3}{4}$ times in the length of head 
and body. Its second ray is divided, the under ray the longer, reaching to within a diameter of the eye of the tip of the third or longest ray. The ventrals reach to the base of the lower caudal rays. Their base is midway between their tips and the edge of the opercle; three or four of its outer rays grow gradually shorter; the outer one is twice the diameter of the eye in length.

Color in spirits light brown on back, abruptly silvery on head and body below the level of middle of eye. The maxillary is dusky and the suborbital and opereular regions are dusky with points of brown over the silver. The pectoral is jet black, changing to white on the lower rays. The ventrals are colored like the pectoral and with lighter inner rays. The dorsal is dusky toward the ends of the rays. The posterior fourth of the anal is abruptly black. The caudal has two dusky spots, which appear in Dr. Steindachner's plate of this species as the interspaces between two white spots. The caudal peduncle is dusky above.

This description is taken from a specimen $10 \mathrm{~cm}$. in length from Wakanoura.

A small specimen, $35 \mathrm{~mm}$. in length, differs in having the pectoral reaching only to below the third dorsal ray. At the symphysis is a wide, flat, triangular barbel, which is very slightly trifid at its lower margin.

This species is apparently identical with Exocotus himundo described and figured from Hongkong. It is not yet recorded from elsewhere. (hirundo, swallow.)

\section{SUMMARY.}

Suborder SYNENTOGNATHI.

Family I. Belonide.

\section{Tylosurus Cocco.}

1. schismatorhynchus (Bleeker); Nagasaki, Wakanoura.

2. giganteus (Schlegel); Nagasaki, Wakanoura.

3. coromandelicus (Van Hasselt); Tsuruga, Yokohama.

4. anastomella (Cuvier and Valenciennes); Yokohama, Tokyo, Matsushima Bay, Hakodate.

Family II. Hemiramphidæ.

\section{Hyporhamphus Gill.}

5. sajori (Schlegel); Aomori, Matsushima, Tokyo, Misaki, Wakanoura, Kobe, Hakata, Nagasaki.

6. kurumeus Jordan and Starks; Chikugo River at Kurume.

7. japonicus (Brevoort). 
Family III. Scombresocide.

3. Cololabis Gill.

8. saira (Brevoort); Awa, Aomori, Hakodate, Otaru.

Family IV. ExосœетіD正.

4. Exonautes Jordan and Evermann.

9. brachycephalus (Günther); Misaki.

5. Cypsilurus Swainson.

10. agoo (Schlegel); Aomori, Tokyo, Miyako in Rikuzchu, Tsuruga, Nagasaki, Hiroshima, Onomichi, Hakata.

11. pæcilopterus (Cuvier and Valenciennes); Hakodate.

12. hirundo (Steindachner); Wakanoura. 


\section{$2 \mathrm{BHL}$ Biodiversity Heritage Library}

Jordan, David Starr and Starks, Edwin Chapin. 1903. "A review of the synentognathous fishes of Japan." Proceedings of the United States National Museum 26(1319), 525-544. https://doi.org/10.5479/si.00963801.26-1319.525.

View This Item Online: https://www.biodiversitylibrary.org/item/32571

DOI: https://doi.org/10.5479/si.00963801.26-1319.525

Permalink: https://www.biodiversitylibrary.org/partpdf/9435

\section{Holding Institution}

Smithsonian Libraries

\section{Sponsored by}

Smithsonian

\section{Copyright \& Reuse}

Copyright Status: NOT_IN_COPYRIGHT

This document was created from content at the Biodiversity Heritage Library, the world's largest open access digital library for biodiversity literature and archives. Visit BHL at https://www.biodiversitylibrary.org. 